\title{
OBITUARIES
}

Obituaries should be submitted by email to Annabel Nicholson at annabel.nicholson@nature.com. All submitted obituaries should be 450 words maximum in length (apart from obituaries for past presidents of the BDA where the length should be 800 words).

Content of the obituary is down to the individual author, and the approval of the family should be given for the obituary prior to submission to the $B D J$.

\section{HENRY LEVISON}

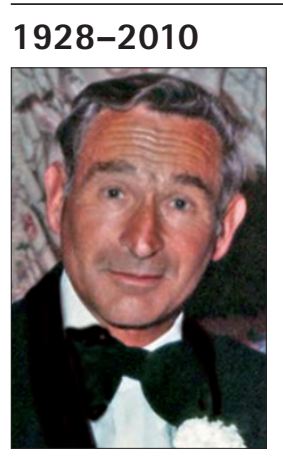

Gaining a scholarship to Southend High School for Boys, the headmaster wisely encouraged Henry to take up a career in dentistry. He qualified in 1951 at Guy's Hospital, where he became a dental house surgeon.

National Service followed, and Henry became a Captain in the Royal Army Dental Corps whilst serving in Egypt. On returning he gained Fellowship in Orthodontics at Eastman Dental Hospital.

Henry then became Chief Dental Officer of the Shetland Islands. Travelling between the islands on the various ferries developed a love of the sea and birds. Whilst there, he found his dental nurse to be struggling with her dental nurse examinations. Asking to see the textbook Henry found to his surprise one had not been published. During a winter spent with the School Health Services mobile dental unit, the text was prepared. Henry's book was published in 1960 - 'Textbook for dental nurses'.

The book was written in Henry's style; meticulous in detail and presented in a dogmatic fashion. The first edition in 1960 had 140 pages. It became a best-seller as the standard textbook for dental nurses and went through nine editions, growing to some 435 pages. Each revision was scrupulously researched to ensure the book was kept up-to-date as dentistry evolved.

His next post was in Anglesey and as an accomplished hill walker Henry scaled every peak in Snowdonia. However, the achievement of an 'O' level in Welsh must have been the really serious challenge. A move to Staffordshire General Hospital as Consultant in Children's Dentistry was followed by a return to Essex; his final post as Chief Community Orthodontist. Upon retirement, he became Emeritus Examiner for the National Examining Board for Dental Nurses.
Outside of dentistry Henry was a family man with a reserved character but had a wicked English sense of humour. He particularly enjoyed the Gilbert and Sullivan operettas and Johann Strauss. Living in Southend brought back an interest in sailing, first gained with a catamaran off Anglesey. In seeking to promulgate his astronomy and sailing skills led to the publication of 'Astro-navigation by calculator - a handbook for yachtsman' (1984). His passion for sailing on the inland waterways of the Netherlands led to the 'Dutch inland sailing pilot' (1988), the first guide in English.

Despite Henry's passing in 2010, 'Levison's textbook for dental nurses' has continued into its 11th Edition in many languages under the direction of Carole Hollins. Fifty-five years on, Henry's 'bible' for dental nurses has helped generations to pursue their career and will continue to do so for many years to come.

Gavin Fenton

\section{JOHN DAVIS}

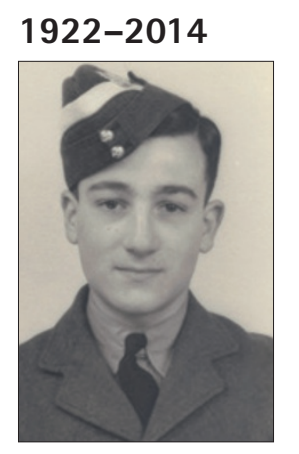

John Davis passed away on 6th October 2014 aged 92. As well as building and running JCtS Davis, he was involved in the British Dental Trade Association (BDTA), BDA, founder of Cordent Dental Trust (CDT) and co-founder then president of British Dental Health Foundation (BDHF).

John was born just as his father Solly, Uncle Joe and their friend Mark Schottlander established Davis Schottlander \& Davis, building from the J\&S Davis dental business started in 1908.

John's dental career started in 1940 but was short-lived as he enlisted in the RAF almost immediately. John flew Hurricanes and Spitfıres with 152 Squadron. He was in West Africa for four years, flying the then secret Takoradi route to get fighter aircraft to the eastern Mediterranean. In 1946 Flight Lieutenant Davis was demobbed and he returned to the family business. In 1953 John restarted JetS Davis which he built into a successful company.

John was instrumental in developing many dental concepts that are taken for granted today, such as the first effective turbine handpiece (Sandri) and disposable products (in 1967 the Solo sterile, disposable needle was launched). At a time of water boilers, he introduced first Electrolux dry heat sterilisers then Melag autoclaves.

He was twice President of BDTA (1966-1967 and 1984-1986). He co-wrote the 'Introduction to Dentistry' training course, the basis for what is still used for dental industry training.

Recognition came with Roll of Honour of both the BDTA and BDA, the Probe Lifetime Achievement Award and Fellowship of the International College of Dentists. The charity CDT was then born, funded initially by JCtS Davis. It supported hundreds of projects by bringing together leading dental clinicians, academics and senior dental industry people. Cordent did much work in the third-world countries where dental care and knowledge was almost non-existent. Projects included equipping a dental health train in South Africa.

In the early 1970s, John, with a few other enthusiastic dental traders and dentists, brought the BDHF into existence. Its purpose was to educate the public on oral health issues.

The difficult economy of the 1980s forced him to sell in 1991. In 2012 his son Daniel bought JetS Davis back.

As an active member of the Association of Jewish Ex-Servicemen (AJEX), he marched annually at the Cenotaph, sold poppies and attended local schools to give talks on his flying experiences.

Married in 1948 to Hilde who predeceased him, John is survived by Daniel, Susan and grandchildren David, Rachel, Joanna and Oliver.

Daniel Davis 